\title{
Effects of Crude Oil Pollution on the Morphology, Growth and Heavy Metal Content of Maize (Zea mays Linn.)
}

\author{
ODIYI, BO; GIWA, GO; *ABIYA, SE; BABATUNDE, OS \\ Department of Biology, Federal University of Technology, Akure, Nigeria \\ "Corresponding Author Email: esabiya@futa.edu.ng
}

\begin{abstract}
This study was designed to investigate the effect of crude oil pollution on the morphology, growth and heavy metal content of maize (Zea mays L.) by analyzing selected physicochemical parameters and heavy metals in soil samples and plant parts using standard field experimental methods. Results from this study show that all the growth parameters of Zea mays planted in the polluted soil were adversely affected by crude oil pollution. The highest mean height for treatments $50 \mathrm{ml}, 100 \mathrm{ml}$ and $150 \mathrm{ml}$ were $33.54 \mathrm{~cm}, 31.34 \mathrm{~cm}$ and $27.44 \mathrm{~cm}$ respectively while that of the control was $87.58 \mathrm{~cm}$. The $\mathrm{pH}$ of the soil increased as the volume of the crude oil increased. Chlorophyll content of the Zea mays leaves reduced with increase in the volume of crude petroleum. Of the plant parts examined, root had the highest content of chromium $(\mathrm{Cr})$ with $0.22 \mathrm{ppm}(150 \mathrm{ml})$, nickel $(\mathrm{Ni})$ with $0.46 \mathrm{ppm}(150 \mathrm{ml})$, lead with $0.06 \mathrm{ppm}(150 \mathrm{ml})$ and cadmium $(\mathrm{Cd})$ with $0.02 \mathrm{ppm}(150 \mathrm{ml})$ while the highest copper $(\mathrm{Cu})$ value of $0.28 \mathrm{ppm}(150 \mathrm{ml})$ was recorded in the leaves $(150 \mathrm{ml})$. Heavy metals concentration significantly increased $(\mathrm{P}<0.05)$ with the increase in volume of crude oil pollution. This study has shown that crude oil polluted soil brings about reduction in the growth, yield and leaf chlorophyll of maize plant. Coupled with increasing heavy metal concentration, this could lead to scarcity and safety concerns in maize consumption in areas impacted by crude oil pollution.
\end{abstract}

DOI: https://dx.doi.org/10.4314/jasem.v24i1.17

Copyright: Copyright $($ C) 2020 Odiyi et al. This is an open access article distributed under the Creative Commons Attribution License (CCL), which permits unrestricted use, distribution, and reproduction in any medium, provided the original work is properly cited.

Dates: Received: 30 November 2019; Revised: 20 December 2019; Accepted: 23 December 2019

Keywords: Crude oil, Pollution, Maize, Effects, Yield, Growth

Crude oil is a naturally occurring complex mixture of hydrocarbon and non-hydrocarbon compounds and at high concentrations can be toxic to living organisms (Nelson-Smith, 1973; Anderson and Labelle, 2000). Over the years, there has been an increase in the demand for crude oil as the major source of energy both for personal and industrial use. As a result of this increasing use, there is a commensurate increase in the production, transportation and refining of crude oil leading to gross pollution of the environment majorly resulting from oil spillages (Rowell, 1977). The occurrence of oil spillage is a global phenomenon occurring in both land and water causing serious problems and hazards to the environment. Nigeria as a major producer and exporter of crude oil has had its own fair share of oil spillage. Soil pollution by crude oil and petroleum products are presently a menace in Nigeria, particularly in the oil producing areas. Anoliefo and Vwioko (1995) noted that oil spillage leads to a general increase in the heavy metal content of soils. This heavy metal pollution is caused by various metals especially copper, nickel, cadmium, zinc, chromium and lead (Hinojosa et al., 2004). Contamination of the soil by crude oil has been reported to adversely affect germination, reduce crop yield and also lead to premature death of plants (Udom et al., 2012). Maize (Zea mays L.) is the most important and most widely distributed cereal in the world after wheat and rice (Nafziger, 2006). It is used for three main purposes, as a staple food crop for human consumption, as feed for livestock and also as raw material for many industrial uses, including biofuel production, starch, flour and alcohol production (Agoda et al., 2011; Oyewo, 2011). It is one of the main staple cereals in Nigeria and many African countries (Oyewo, 2011). Nigeria being a major exporter of crude oil has experienced several oil spills which affected agricultural lands and agricultural produce. Maize, as one of the staple food in Nigeria is adversely affected. There is a need therefore to investigate the effect of crude oil on the growth and performance of maize grown in a crude oil polluted soil. The objective of this paper is to evaluate the effects of crude oil on the morphology, growth and heavy metal content of maize (Zea mays Linn.)

\section{MATERIALS AND METHODS}

Study Site: The experiment was carried out in a screen house.

Sources of Material: Loamy soil was collected from a pristine vegetation in University. Maize seeds were purchased at a local market in Akure metropolis while 
the crude oil used was collected from Warri Refining and Petrochemical Company.

Experimental Design: The experiment involved polluting $10 \mathrm{~kg}$ of loamy soil with $50 \mathrm{ml}, 100 \mathrm{ml}$ and $150 \mathrm{ml}$ of crude oil. The oil-soil mixture was turned thoroughly and left for 2 days to allow for proper mixing. Another pot with no crude oil $(0 \mathrm{ml})$ served as the control. This set up was replicated five times and was arranged in a completely randomized design (CRD). Three weeks old seedlings of maize earlier raised in a nursery was transplanted into the experimental pots and left for a total duration of 14 weeks.

Measurement of Plant Growth Parameters: During the course of the experiment, growth parameters were measured on a two weekly basis. Plant height was measured with the aid of a measuring tape, number of leaves was physically counted and leaf area measured following Agbogidi and Ofuoko (2005). It was done by measuring the length and breadth of the maximum leaf per plant and multiplying by the correction factor 0.75 . At harvest, fresh and dry weight was determined. Fresh weight was obtained by weighing the uprooted and rinsed maize plant using Ohaus Analytical balance (Valour500 3dp). Dry weight was determined by first drying the plant in Gallenhamp drying cabinet at $105^{\circ}$ $\mathrm{C}$ for 24 hours and then followed by weighing in an Ohaus Analytical balance (Valour500 3dp).

Determination of total chlorophyll content: The chlorophyll of plant samples was determined using the method of Heidcamp (2003) which involves the extraction of the chlorophyll of $1 \mathrm{~g}$ of each leaf with $10 \mathrm{ml}$ of $80 \%$ acetone, the mixture of each extract was sieved using muslin cloth poured in a curvette. The optical density (OD) of each extract was read off at $652 \mathrm{~nm}$ using Uv-vis spectrophotometer (spectrum Lab. 7555). The chlorophyll content $(\mathrm{mg} / \mathrm{l})$ of each leaf was determined by dividing the optical density reading with 34.5 .

Determination of plant heavy metals: Heavy metal analysis was carried out on plant leaves, stems and roots. $2 \mathrm{~g}$ of pulverized sample was put into a conical flask. $10 \mathrm{ml}$ of $\mathrm{HNO}_{3}$ was added, then the mixture was boiled with steady heat till it almost dried. This was allowed to cool before $50 \mathrm{ml}$ distilled water was added and boiled for 10 minutes. Mixture was allowed to cool again and then filtered. The mixture was made up to a known volume. Heavy metal analysis was done using Atomic Absorption Spectrophotometer Buck Scientific 210 VGP model. The instrument was first calibrated with already prepared working standard of corresponding elements to be analyzed after which the concentration of the element in each sample was determined.

$$
\text { Conc. } m g / k g=\frac{A A S \text { reading } x \text { Dilution Factor }}{\text { Weight of sample }}
$$

Soil analysis: Soil samples were analysed before and after the experiment. Analysis carried out to determine soil includes. Soil $\mathrm{pH}$ was determined using a $\mathrm{pH}$ meter ( $\mathrm{pH}-2$ Hanna) which was standardized with buffer 4 solution. Soil organic carbon was determined using the Walkley-Black wet oxidation method (Walkley and Black, 1934). Total Nitrogen was determined using Total N-Kjeldahl procedure (Bremner and Keeney, 1966). Available Phosphorus was determined by using Bray method (Bray and Kurtz, 1945). Soil particles sizes were estimated using the Hydrometer method (Bouyoucos, 1962).

Data analysis: All data obtained was subjected to Analysis of Variance (ANOVA), where significant differences exist, treatment means where compared at 0.05 significant level using Duncan's new Multiple Range Test SPPS 21.0 software was used for all statistical analysis.

\section{RESULTS AND DISCUSION}

The results of this study are presented in figures 1-8 and tables 1-5. Poor growth and slender stems were observed in most of the treated $Z$. mays plants. Plants in both $100 \mathrm{ml}$ and $150 \mathrm{ml}$ pots had stunted growth, chlorosis and wilting of leaves, necrosis, the soil was dried, hardened and compacted. There was $40 \%$ death in treatment $150 \mathrm{ml}$. The growth parameters of Zea mays L. plants were adversely affected by the crude oil pollution. The effects were concentration dependent as the growth parameters were reduced as concentration of crude oil applied increased. Plant height was highest in control plant when compared to the treatments. The most affected by crude oil pollution were those treated with $150 \mathrm{ml}$ crude oil. In the treatments, the highest mean height observed for plant with treatment $50 \mathrm{ml}$, $100 \mathrm{ml}$ and $150 \mathrm{ml}$ were $33.54 \mathrm{~cm}$ (week 10), 31.34 $\mathrm{cm}$ (week 8) and $27.44 \mathrm{~cm}$ (week 8) respectively (see figure 1). Similar trend was observed by Etukudoh and Chukwumati (2016) that plants height were higher in the soil without pollution as compared to the plants in polluted soil. The reduction in height of the plants could be due to unfavourable soil conditions mainly due to insufficient aeration following a decrease in the air filled pore spaces (Atuanya, 1987), effects on soil microbes (Benka-Coker and Ekundayo, 1995), presence of toxic oil components (Siddiqui and Adams, 2002), reduced biochemical activities as well as presence of heavy metals (Agbogidi and Egbuchua, 
2010) and a disruption in the soil water-plant interrelationship (Agbogidi, 2011).

The result of the effect of crude oil on the stem girth measurements of Zea mays are presented in "figure 2". Mean girth size followed the trend control $>50 \mathrm{ml}>100 \mathrm{ml}>150 \mathrm{ml}$. The highest mean stem girth obtained for control and treatments were $3.72 \mathrm{~cm}$ (control), $2.84 \mathrm{~cm}(50 \mathrm{ml}), 2.22 \mathrm{~cm}(100 \mathrm{ml})$ and 2.04 $\mathrm{cm}(150 \mathrm{ml})$. Reports from various oil contaminants on soil by researchers revealed that stem girth values were found to decrease as the concentration increased. This current study follows this trend and agrees with the findings of Okonokhua et al., (2007). They reported a reduction in stem girth of maize as concentration of pollutant increases. Crude oil pollution in all treatments resulted in reduction in the mean number of leaves when compared with control (Figure 3). Control and $50 \mathrm{ml}$ had their highest mean number of leaves of 8.6 and 5.8 at week 10 while 100 $\mathrm{ml}$ and $150 \mathrm{ml}$ had their highest mean number of leaves at week 8 (5.2 and 4.5 respectively). Generally, for all the treated maize plants (from week 6) the leaves showed chlorosis and wilting. At week 12 to 14 the result showed that the number of leaves reduced drastically when compared to the previous weeks and this could be because some leaves turned brown, withered and collapsed, mostly in treated plants. According to (Udo and Fayemi, 1975), this could be as a result of reduction in soil aeration due to thin film layer formation on the topsoil by the applied crude oil thereby reducing air passage through the soil pores, leading to the suffocation of the maize plants and hence, reduction in the number of leaves. The fresh and dry weights of $(\mathrm{g})$ of $Z$. mays were reduced by the application of the crude oil (Figure 4 and 5 respectively). Fourteen weeks after transplanting, the lowest mean value for fresh weight among the treated plants was observed in $150 \mathrm{ml}(21 \mathrm{~g})$ while the control had the highest mean weight of $85 \mathrm{~g}$. The $50 \mathrm{ml}$ and $100 \mathrm{ml}$ had the same mean dry weight of $30 \mathrm{~g}$ and 29.6 $\mathrm{g}$ respectively. There were significant lower yield and growth in plants grown in polluted soils compared to those of the control. This is in agreement with the findings of Okonokhua et al. (2007) and Anoliefo et al. (2006) in maize sown in oil polluted soils. In their studies, they reported a reduction in growth parameters and yield as concentration of pollutant increased. Ojimba and Iyagba (2012) reported the decreased output of horticultural crops in crude oil polluted farms as compared with the unpolluted farms.

Results of the effect of crude oil on the leaf area of Zea mays is presented in "figure 6". Leaf area was significantly $(\mathrm{P}>0.05)$ affected by the crude oil application. The highest mean leaf area for all the treatments and the control was at week $10,50 \mathrm{ml}$ was
$228.5 \mathrm{~cm}^{2}, 100 \mathrm{ml}\left(185.5 \mathrm{~cm}^{2}\right), 150 \mathrm{ml}\left(144.5 \mathrm{~cm}^{2}\right)$ and control $\left(424.5 \mathrm{~cm}^{2}\right)$. Chlorophyll content of the Zea mays leaves was significantly $(\mathrm{P}>0.05)$ affected by the application of crude oil to the soil (figure 7). Control had the highest mean chlorophyll content $(72.01 \mathrm{mg} / \mathrm{l})$ and it was significantly different $(\mathrm{P}<$ $0.05)$ from $50 \mathrm{ml}(66.02 \mathrm{mg} / \mathrm{l}), 100 \mathrm{ml}(58.10 \mathrm{mg} / \mathrm{l})$ and that of $150 \mathrm{ml}$ which had the least mean chlorophyll content $(43.50 \mathrm{mg} / \mathrm{l})$. The reduction of the chlorophyll content of the plant could be due to the interference of the oil on the ability of the plant to absorb some of the mineral nutrients. Minerals like magnesium, iron, boron, and manganese are essential for chlorophyll synthesis (Campbell, 1996; Kent, 2000; Taylor et al., 2001). The results of the effect of crude oil on the soil physicochemical parameters are presented in "figure 7" and "table 1". pH of the soil increased with increasing concentration of crude oil following the trend $150 \mathrm{ml}>100 \mathrm{ml}>50 \mathrm{ml}>$ control (figure 7). Control soil had the least $\mathrm{pH}$ value (6.7) and $150 \mathrm{ml}$ treatment had the highest mean $\mathrm{pH}$ value (7.64) while $50 \mathrm{ml}$ and $100 \mathrm{ml}$ treatments had intermediate values (7.05 and 7.38 respectively). Other parameters are presented in "table 1". The organic carbon content of the soil was significantly different in all treatments at $\mathrm{p}<0.05$. The control had the lowest organic carbon $(3.41 \mathrm{cmol} / \mathrm{kg})$ while $150 \mathrm{ml}$ had the highest mean organic carbon content $(8.02 \mathrm{cmol} / \mathrm{kg})$. The available phosphorus (P) decreased as the concentration of crude oil increased. There was no significant difference $(\mathrm{P}>0.05)$ between control $(156.4 \mathrm{ppm})$ and $50 \mathrm{ml}(151.4 \mathrm{ppm})$ while $150 \mathrm{ml}(99.9 \mathrm{ppm})$ was significantly different from all other treatments including the control. The application of crude oil to soil was observed to increase the total nitrogen $(\mathrm{N})$ in the soil. Control $(0.01 \%)$ had the least nitrogen while $150 \mathrm{ml}(0.027 \%)$ had the highest. There was no significant difference in the nitrogen between $50 \mathrm{ml}$ and $100 \mathrm{ml}(0.019 \%$ and $0.02 \%$ respectively $)$ at $\mathrm{P}>$ 0.05 . The silt, clay and sand constituents were not significantly different $(\mathrm{P}>0.05)$ in both treated and control soil. These results indicated that crude oil in the soil has a significant effect on soil properties like nitrogen content, phosphorus, carbon and heavy metals. This observation is in agreement with earlier reports by Agbogidi and Egbuchua (2010) who noted that oil in soil has deleterious effects on the biological, chemical and physical properties of the soil depending on the dose, type of the soil and other factors. Soil $\mathrm{pH}$ which is a major factor influencing the availability of elements in the soil for plant uptake (Okonokhua et al., 2007) was observed to increase with increasing concentration of crude oil. This is in agreement with Vwioko et al., 2008. He reported that contamination of soil increases its $\mathrm{pH}$ from acidic to neutral. 


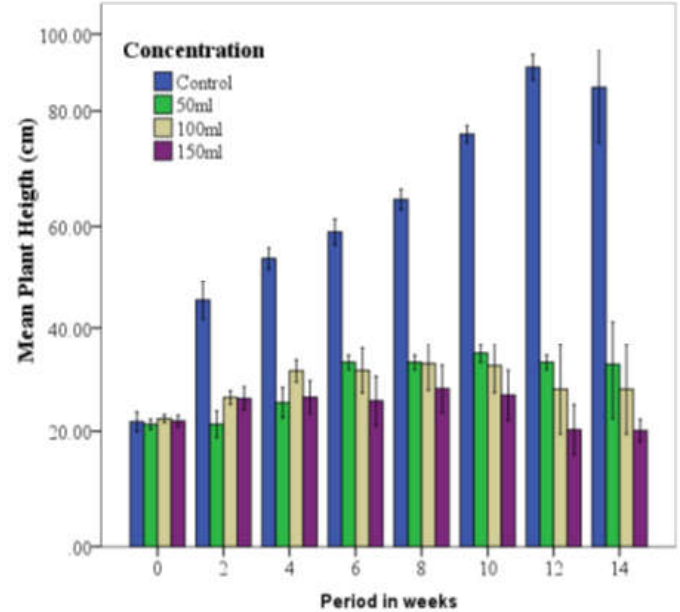

Fig 1: Effect of crude oil at various volumes on plant height $(\mathrm{cm})$ of Zea mays $\mathrm{L}$ during the growing period

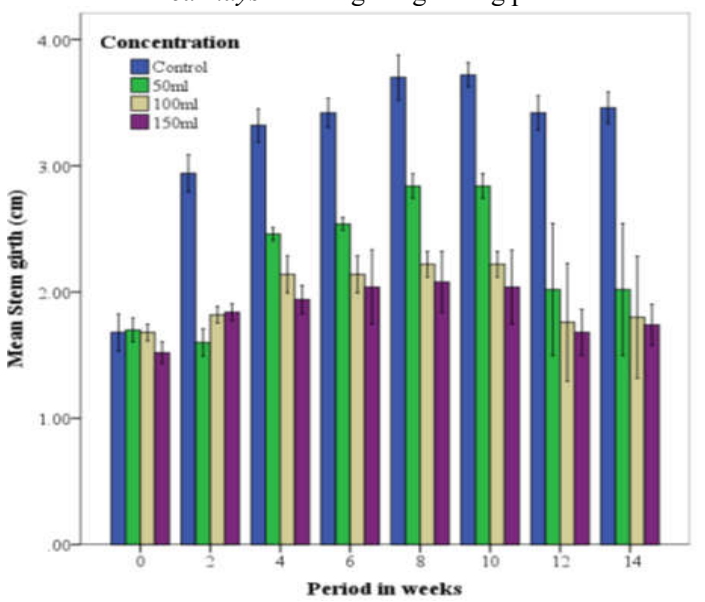

Fig 2: Effect of crude oil at various volumes on plant stem girth $(\mathrm{cm})$ of Zea mays $\mathrm{L}$ during the growing period

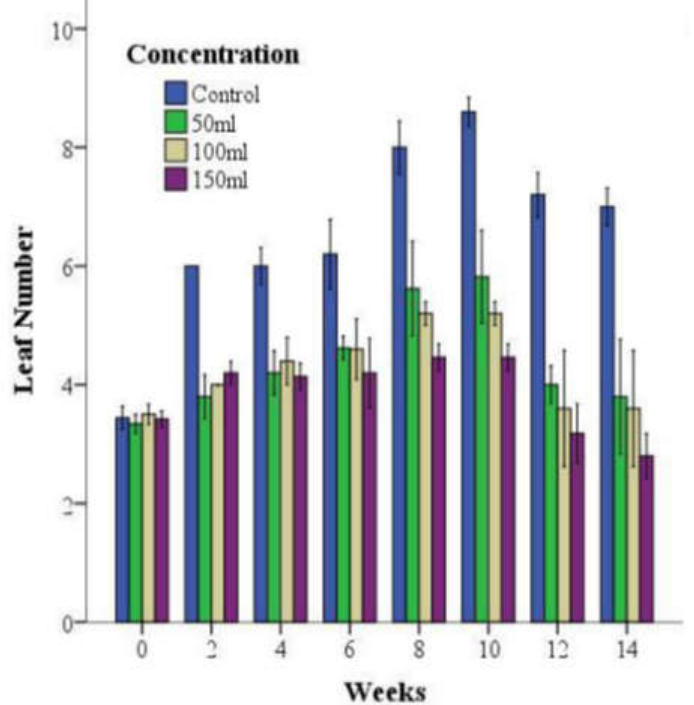

Fig 3: Effect of crude oil at various volumes on number of leaves of Zea mays $\mathrm{L}$ during the growing period

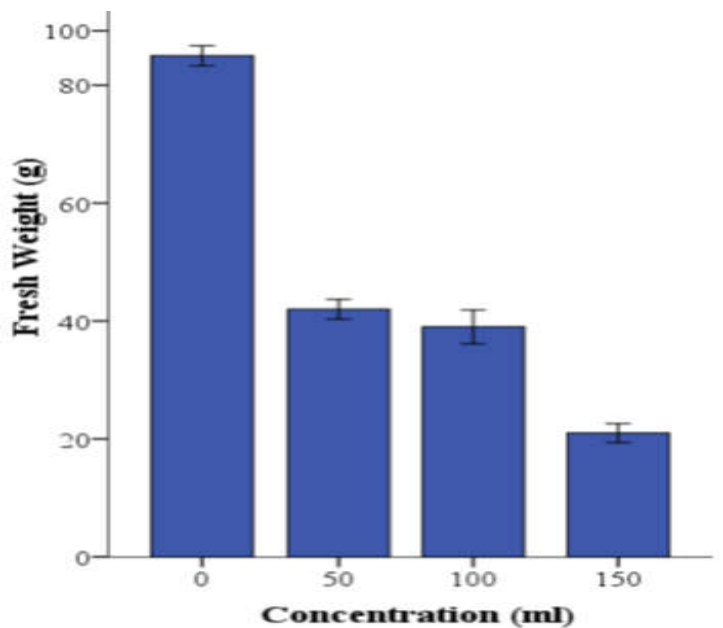

Fig 4: Effect of crude oil on fresh weight (g) of Zea may L at harvest.

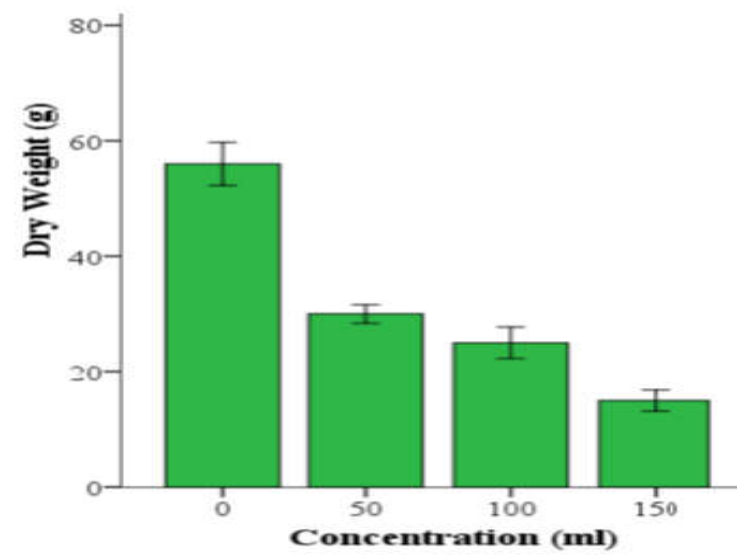

Fig 5: Effect of crude oil on dry weight (g) of Zea may L at harvest.

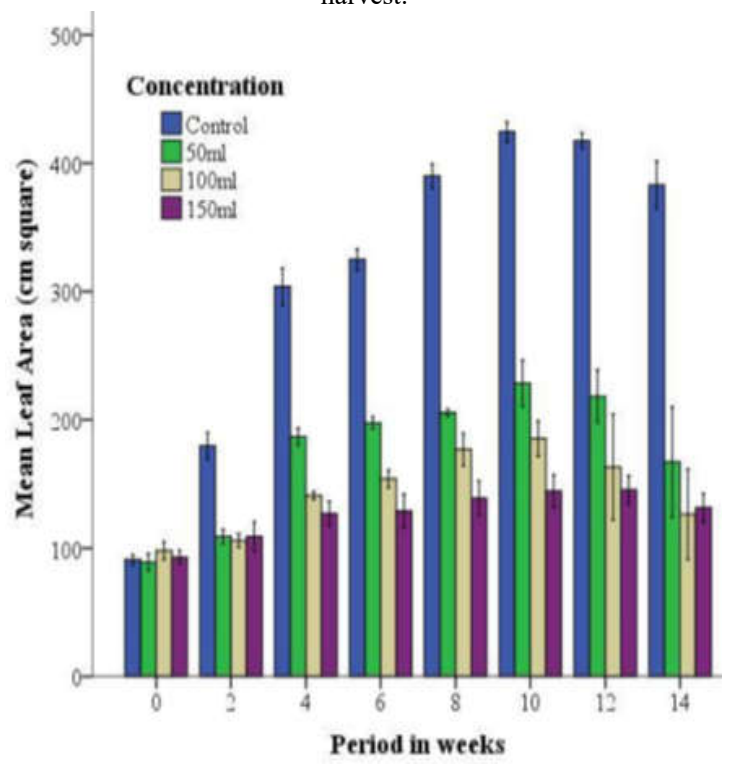

Fig 6: Effect of crude oil application at various volumes on the leaf area of Zea mays L during the growing period 

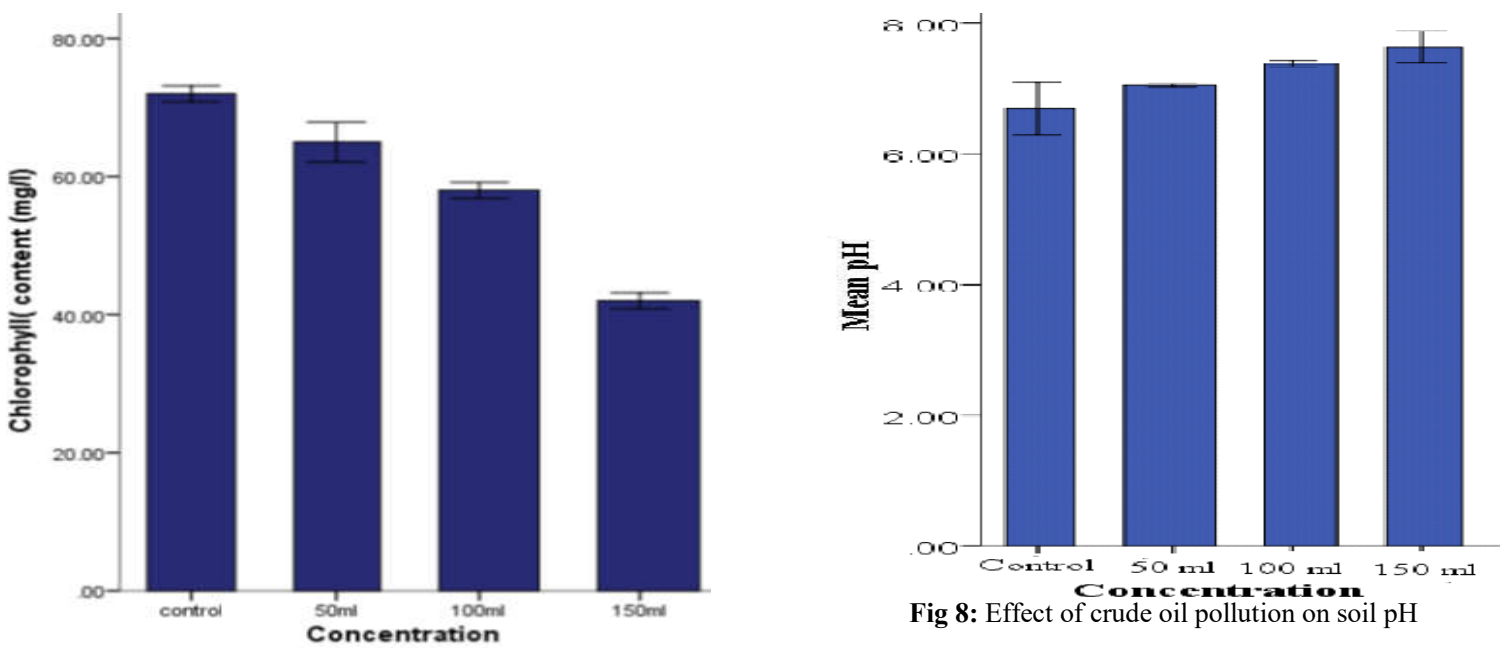

Fig 7: Effect of crude oil pollution on chlorophyll content of Zea

\begin{tabular}{|c|c|c|c|c|c|c|c|}
\hline \multirow{2}{*}{$\begin{array}{l}\text { Treatment } \\
(\mathrm{ml})\end{array}$} & \multicolumn{7}{|c|}{ Heavy Metals (ppm) } \\
\hline & $\overline{\mathrm{OC}, \mathrm{cmol} / \mathrm{kg}}$ & $\mathbf{P}, \mathbf{p p m}$ & $\mathrm{N}, \%$ & Sand & Clay & Silt, \% & Type \\
\hline$\overline{00}$ & $3.41 \pm 0.12^{\mathrm{a}}$ & $156.40 \pm 2.48^{\mathrm{c}}$ & $0.010 \pm 0.000^{\mathrm{a}}$ & $13.3 \pm 1.67^{\mathrm{a}}$ & $7.3 \pm 0.06^{\mathrm{a}}$ & $79.4 \pm 3.46^{\mathrm{a}}$ & Loamy \\
\hline 50 & $4.08 \pm 0.09^{\mathrm{b}}$ & $151.40 \pm 0.70^{\mathrm{c}}$ & $0.019 \pm 0.0003^{b}$ & $12.4 \pm 0.23^{\mathrm{a}}$ & $7.3 \pm 0.12^{\mathrm{a}}$ & $80.3 \pm 0.17^{\mathrm{a}}$ & Loamy \\
\hline 100 & $7.03 \pm 0.02^{\mathrm{c}}$ & $132.40 \pm 0.63^{\mathrm{b}}$ & $0.020 \pm 0.0032^{\mathrm{b}}$ & $12.9 \pm 0.58^{\mathrm{a}}$ & $7.4 \pm 0.23^{\mathrm{a}}$ & $79.7 \pm 0.58^{\mathrm{a}}$ & Loamy \\
\hline 150 & $8.02 \pm 0.04^{\mathrm{d}}$ & $99.90 \pm 2.62^{\mathrm{a}}$ & $0.027 \pm 0.0032^{\mathrm{c}}$ & $13.2 \pm 1.67^{\mathrm{a}}$ & $7.3 \pm 0.13^{\mathrm{a}}$ & $79.4 \pm 2.54^{\mathrm{a}}$ & Loamy \\
\hline
\end{tabular}

Mean \pm standard error represent 5 (five) replicates. Means value with the same alphabet down the column are not significantly different from each other using Duncan's New Multiple Range Test (DNMRT) at P $>0.05$.

Table 2: Heavy metals concentration (ppm) in Zea mays L. leaves in the polluted and unpolluted soil

\begin{tabular}{llll}
\hline \multirow{2}{*}{ Treatments (ml) } & \multicolumn{3}{c}{ Heavy Metals (ppm) } \\
\cline { 2 - 4 } & $\mathbf{C r}$ & $\mathbf{C u}$ & $\mathbf{N i}$ \\
\hline 00 & $0.03 \pm 0.01^{\mathrm{a}}$ & $0.20 \pm 0.00^{\mathrm{a}}$ & $0.05 \pm 0.01^{\mathrm{a}}$ \\
50 & $0.05 \pm 0.01^{\mathrm{ab}}$ & $0.20 \pm 0.00^{\mathrm{a}}$ & $0.08 \pm 0.01^{\mathrm{a}}$ \\
100 & $0.06 \pm 0.01^{\mathrm{b}}$ & $0.26 \pm 0.02^{\mathrm{a}}$ & $0.11 \pm 0.01^{\mathrm{ab}}$ \\
150 & $0.07 \pm 0.01^{\mathrm{b}}$ & $0.28 \pm 0.02^{\mathrm{a}}$ & $0.37 \pm 0.18^{\mathrm{b}}$ \\
\hline
\end{tabular}

Mean \pm standard error represent 5 (five) replicates. Mean values with the same alphabet down the column are not significantly different from each other using Duncan's New Multiple Range Test (DNMRT) at P $>0.05$

Table 3: Heavy metals concentration (ppm) in Zea mays stem in the polluted and unpolluted soil.

\begin{tabular}{lccccc}
\hline & \multicolumn{5}{c}{ Heavy Metals (ppm) } \\
\cline { 2 - 6 } Treatments (ml) & $\mathbf{C r}$ & $\mathbf{C u}$ & $\mathbf{N i}$ & $\mathbf{P b}$ & $\mathbf{C d}$ \\
\hline 00 & $0.06 \pm 0.01^{\mathrm{a}}$ & $0.03 \pm 0.01^{\mathrm{a}}$ & $0.02 \pm 0.00^{\mathrm{a}}$ & $0.01 \pm 0.00^{\mathrm{a}}$ & $0.01 \pm 0.00^{\mathrm{a}}$ \\
50 & $0.09 \pm 0.01^{\mathrm{b}}$ & $0.03 \pm 0.01^{\mathrm{a}}$ & $0.04 \pm 0.01^{\mathrm{a}}$ & $0.01 \pm 0.01^{\mathrm{a}}$ & $0.01 \pm 0.00^{\mathrm{a}}$ \\
100 & $0.10 \pm 0.01^{\mathrm{b}}$ & $0.03 \pm 0.00^{\mathrm{a}}$ & $0.10 \pm 0.00^{\mathrm{b}}$ & $0.02 \pm 0.01^{\mathrm{b}}$ & $0.01 \pm 0.00^{\mathrm{a}}$ \\
150 & $0.12 \pm 0.01^{\mathrm{c}}$ & $0.05 \pm 0.01^{\mathrm{a}}$ & $0.15 \pm 0.00^{\mathrm{b}}$ & $0.03 \pm 0.01^{\mathrm{c}}$ & $0.02 \pm 0.00^{\mathrm{b}}$ \\
\hline
\end{tabular}

Mean \pm standard error represent 5 (five) replicates. Mean values with the same alphabet down the column are not significantly different from each other using Duncan's New Multiple Range Test (DNMRT) at $P>0.05$.

Table 4: Heavy metals concentration (ppm) in Zea mays L. root in polluted and unpolluted soil.

\begin{tabular}{|c|c|c|c|c|c|}
\hline \multirow[b]{2}{*}{ Treatments $(\mathrm{ml})$} & \multicolumn{5}{|c|}{ Heavy Metals (ppm) } \\
\hline & $\mathrm{Cr}$ & $\mathbf{C u}$ & $\mathbf{N i}$ & $\mathbf{P b}$ & Cd \\
\hline$\overline{00}$ & $0.11 \pm 0.00^{\mathrm{a}}$ & $0.04 \pm 0.01^{\mathrm{a}}$ & $0.24 \pm 0.02^{\mathrm{a}}$ & $0.01 \pm 0.00^{\mathrm{a}}$ & $0.01 \pm 0.00^{\mathrm{a}}$ \\
\hline 50 & $0.14 \pm 0.01^{\mathrm{b}}$ & $0.05 \pm 0.02^{\mathrm{ab}}$ & $0.25 \pm 0.02^{\mathrm{a}}$ & $0.03 \pm 0.01^{\mathrm{ab}}$ & $0.01 \pm 0.00^{\mathrm{a}}$ \\
\hline 100 & $0.20 \pm 0.01^{\mathrm{c}}$ & $0.05 \pm 0.01^{\mathrm{ab}}$ & $0.38 \pm 0.01^{\mathrm{b}}$ & $0.05 \pm 0.01^{\mathrm{c}}$ & $0.01 \pm 0.00^{\mathrm{a}}$ \\
\hline 150 & $0.22 \pm 0.01^{\mathrm{c}}$ & $0.07 \pm 0.02^{\mathrm{b}}$ & $0.46 \pm 0.02^{\mathrm{c}}$ & $0.06 \pm 0.01^{\mathrm{c}}$ & $0.02 \pm 0.00^{\mathrm{b}}$ \\
\hline
\end{tabular}

Mean \pm standard error represent 5 (five) replicates. Mean values with the same alphabet down the column are not significantly different from each other using Duncan's New Multiple Range Test (DNMRT) at $P>0.05$.

Results of the heavy metal concentration in leaves, stems and roots are presented in tables " 2,3 and 4 " respectively. Copper $(\mathrm{Cu})$, Nickel $(\mathrm{Ni})$, Chromium $(\mathrm{Cr})$, Cadmium $(\mathrm{Cd})$ and Lead $(\mathrm{Pb})$ contents in leaves, stem and root were higher in polluted soil than unpolluted soil. The higher concentrations of heavy metals in leaves, stem and root of the treated Zea mays plants could be as a result of the roots absorbing the 
heavy metals present in treated soil and translocating to other parts of the maize plant. This has been shown by Baker et al. (2000) that certain plants do not only accumulate metals in the roots but also translocate from roots to the leaves or shoots. Although the concentration of heavy metals in the leaves stems and roots of treated plants were below the toxic level of 100 ppm (Charman and Murphy, 1992), heavy metals have a great tendency of accumulating in human organs over time. Heavy Metals present in the polluted soil was slightly higher than that of the control soil. This suggests that heavy metals are present in crude oil and their concentration depend on the intensity of pollution, this observation is in line with earlier report of Atuanya (1987) which states that the concentration of heavy metals present in soil polluted with crude oil depends on the quantity of crude oil present in the soil.

Table 5: Heavy metals concentration in polluted and unpolluted soil

\begin{tabular}{|c|c|c|c|c|c|c|c|c|}
\hline \multirow[b]{2}{*}{$\begin{array}{l}\text { Treatment } \\
(\mathrm{ml})\end{array}$} & \multicolumn{8}{|c|}{ Heavy Metals (ppm) } \\
\hline & $\mathbf{P b}$ & $\mathbf{F e}$ & $\mathbf{C d}$ & Zn & Mn & $\mathrm{Cu}$ & $\mathbf{N i}$ & $\mathrm{Cr}$ \\
\hline$\overline{00}$ & $0.30 \pm 0.09^{\mathrm{a}}$ & $60.00 \pm 2.89^{\mathrm{a}}$ & $0.02 \pm 0.01^{\mathrm{a}}$ & $0.15 \pm 0.03^{\mathrm{a}}$ & $2.16 \pm 0.44^{\mathrm{a}}$ & $0.06 \pm 0.01^{\mathrm{a}}$ & $0.14 \pm 0.02^{\mathrm{a}}$ & $0.10 \pm 0.01^{\mathrm{a}}$ \\
\hline 50 & $0.30 \pm 0.01^{\mathrm{a}}$ & $61.00 \pm 0.64^{\mathrm{a}}$ & $0.02 \pm 0.00^{\mathrm{a}}$ & $0.25 \pm 0.01^{b}$ & $2.10 \pm 0.06^{\mathrm{a}}$ & $0.06 \pm 0.01^{\mathrm{a}}$ & $0.17 \pm 0.01^{\mathrm{a}}$ & $0.22 \pm 0.06^{\mathrm{b}}$ \\
\hline 100 & $0.30 \pm 0.01^{\mathrm{a}}$ & $62.50 \pm 0.29^{\mathrm{a}}$ & $0.02 \pm 0.01^{\mathrm{a}}$ & $0.34 \pm 0.02^{\mathrm{c}}$ & $3.30 \pm 0.17^{b}$ & $0.10 \pm 0.01^{\mathrm{b}}$ & $0.17 \pm 0.02^{\mathrm{a}}$ & $0.24 \pm 0.02^{\mathrm{b}}$ \\
\hline 150 & $0.31 \pm 0.03^{\mathrm{a}}$ & $68.88 \pm 0.46^{\mathrm{b}}$ & $0.03 \pm 0.01^{\mathrm{a}}$ & $0.35 \pm 0.01^{\mathrm{c}}$ & $4.00 \pm 0.11^{b}$ & $0.11 \pm 0.01^{\mathrm{b}}$ & $0.18 \pm 0.01^{\mathrm{a}}$ & $0.24 \pm 0.01^{\mathrm{b}}$ \\
\hline
\end{tabular}

Conclusion: Various contaminants including crude oil, spent engine oil and heavy metals have been found to significantly affect the growth and performances of various plant species. This study has shown that crude oil polluted soil has a significant effect on the growth and yield of maize. In a country like Nigeria where maize cultivation is very high, incidences of crude oil pollution can led to significant loss in yield of this important crop thereby exacerbating the already existing food security challenges of the Nation.

\section{REFERENCE}

Adewole, MG; Moyinoluwa, DA (2012). Effect of Crude Oil on the Emergence and Growth of Cowpea in Two Contrasting soil types from Abeokuta, Southwestern Nigeria. Asian Journal of Applied Science 5(4): 232-239

Agbogidi, OM (2011). Screening six cultivars of cowpea (Vigna unguiculata L.Walp) for adaptation to soil contaminated with spent engine oil. Academia Arena 2(4): 33-40

Agbogidi, OM; Egbuchua, CO (2010). Heavy metal concentrations of soil contaminated with spent engine oil in Asaba, Delta State. Acta Agronomica Nigeriana 10(1): 65-69

Agbogidi, OM; Eruotor, PG; Akparobi, SO (2007). Effects of crude oil levels on the growth of maize (Zea mays L). American Journal of Food Technology 2(6): 529-535

Agbogidi, OM; Nweke, FU; Eshegbeyi, OF (2005). Effects of soil pollution by crude oil on seedling growth of Leucaena leucocephala (Lam. De
Witt). Global Journal of Pure Applied Science 11: 453-456

Agoda, S; Atanda, S; Usanga, OE; Ikotun, I; Isong, IU (2011). Post-harvest food losses reduction in maize production in Nigeria. African Journal of Agricultural Research 6: 4833- 4839

Anderson, CM; LaBelle, RP (2000). Update of comparative occurrence rates for offshore oil spills. Spill Science Technology Bulletin 6(5/6): 303-321

Anoliefo, GO; Vwioko, DE (1995). Effects of spent lubricating oil on the growth of Capsicum annum L. and Lycopersicon esculentum Mill. Environmental Pollution 88: 361-364

Anoliefo, GO; Isikhuemhen, O; Ohimain, E (2006). Sensitivity studies of the common bean (Vigna unguiculata) and maize (Zea mays) to different soil types from the crude oil drilling site at Kutchalli. Nigeria. Journal of Soils and Sediments 6(1): $30-36$

Atuanya, EJ (1987). Effect of oil pollution on physical and chemical properties of oil, a case study of waste oil contaminated Delta Soil in Bendel State, Nigeria. Journal Applied Science 55: 155-176

Baker, AJM; McGrath, SP; Reeves, RD; Smith, JAC (2000). Metal Hyperaccumulator Plants: A Review of the Ecology and Physiology of a Biological Resource for Phytoremediation of Metal-Polluted Soils. In: Terry N and Banuelos $\mathrm{G}$ (eds.) Phytoremediation of Contaminated Soil and Water. Lewis Publishers, Boca Raton, pp. 85-108 
Benka-Coker, MO; Ekundayo, JA (1995). Effects of an oil spill on soil physic chemical properties of a spill site in the Niger Delta Area of Nigeria. Environmental Monitoring and Assessment 36(2): $93-104$

Bray, RH; Kurtz, LT (1945). Determination of total organic and available forms of phosphorus in soils. Soil Science 59:39-45

Bremner, JM; Keeney, DR; (1966). Determination of nitrogen in soils: 3. Exchangeable ammonium, nitrate and nitrite by extraction-distillation methods. Soil Sci. Soc. Am. Proc. 30:577-582

Bouyoucos, GF (1962). Hydrometer method improved for making particle size analysis of soils. Agronomy Journal 54:464-465

Campbell, NA (1996). Biology 4th edition. The Benjamin/Cummings Publishing Company Inc., California

Charman, PE; Murphy, BW (1992). A soil conservation handbook for New South Wales in soil. Their properties and management. Sydney University Press, Sydney, pp 20-21

Etukudoh, NE; Chukwumati, JA (2016). Effects of soil amendments on selected growth parameters of Maize plants (Zea Mays L) in Crude Oil polluted and unpolluted soil. Scholarly Journal of Agricultural Science 6(4): 126-135

Heidcamp, W (2003). Handbook on determination of chlorophyll content in spinach leaves, p. 1

Hinojosa, MB; Carreira, JA; Ruız, RG; Dick, RP (2004). Soil moisture pre-treatment effects on enzyme activities as indicators of heavy metal contaminated and reclaimed soils. Soil Biology and Biochemistry 36: 1559- 1568

Kent, M (2000). Advanced Biology. Oxford University Press, UK, p. 623

Nafziger, ED (2006). Inter and Intra-plant competition in corn. Crop Management 5(1)

Nelson-Smith, A (1973). Oil Pollution and Marine Ecology. Plenum Press, New York

Ojimba, TP; Iyagba, AG (2012). Effects of crude oil pollution on Horticultural crops in Rivers State,
Nigeria. Global Journal of Science Frontier Research Agriculture and Biology 12(4): 37-43

Okonokhua, BO; Ikhajiagbe, B; Anoliefo, GO; Emede, TO (2007). The Effects of Spent Engine Oil on Soil Properties and Growth of Maize (Zea mays L.). Journal of Applied Science and Environmental Management 11(3):147 - 152

Omosun, G; Markson, AA; Mbanasor, O (2008). Growth and Anatomy of Amaranthus Hybridus as Affected by Different Crude Oil Concentrations. American-Eurasian Journal of Scientific Research 3(1): 70-74

Oyewo, IO (2011). Technical Efficiency of Maize Production in Oyo State. Journal of Economics and International Finance 3: 211-216

Rowell, MJ (1977). The effect of crude oil spills on soils: A review of literature. In: Toogood JA (ed) The Reclamation of Agricultural Soils after Oil Spills Part 1. Research, Alberta Institute of Pedology, Canada, pp 1-33

Siddiqui, S; Adams, WA (2002). The fate of diesel hydrocarbons in soils and their effects on the germination of perennial ryegrass. Environmental Toxicology 17(1): 49-62

Taylor, DJ; Green, NPO; Stout, R (2002). Biological Science 3rd edition. Cambridge University Press, Cambridge

Udo, EJ; Fayemi, AAA (1975). The effect of oil pollution of soil on germination, growth and nutrient uptake of corn. Journal of Environmental Quality 4: 537-540

Udom, BE; Ano, AO; Chukwu, W (2012). Contaminant limit (c/p index) of heavy metals in spent oil contaminated soil bioremediated with legume plants and nutrients. Journal of Soil Science 22:144-152

Walkley, A; Black, IA (1934). An examination of the Degtjareff method for determining organic carbon in soils: Effect of variations in digestion conditions and inorganic soil constituents. Soil Science 63:251-263

Yao, H; Xu, J; Huang, C (2003). Substrate utilization pattern, biomass and activity of microbial communities in a sequence of heavy metal polluted paddy soils. Geoderma 115: 139 - 148 . 